3. de Jong $D$, Vasmel WL, de Boer JP, Verhave G, Barbe $E$, Casparie MK, van Leeuwen FE. Anaplastic large-cell lymphoma in women with breast implants. JAMA 2008;300:2030-2035.

4. Bizjak M, Selmi C, Praprotnik S, Bruck O, Perricone C, Ehrenfeld M, Shoenfeld Y. Silicone implants and lymphoma: the role of inflammation. J Autoimmun 2015;65:64-73.

5. Sieber DA, Adams WP Jr. What's your micromort? A patient-oriented analysis of breast implant-associated anaplastic large cell lymphoma (BIAALCL). Aesthet Surg J 2017;37:887-891.

6. Clemens MW, Medeiros $\amalg$, Butler $C E$, Hunt KK, Fanale MA, Horwitz $S$, Weisenburger DD, Liu J, Morgan EA, Kanagal-Shamanna R, Parkash V, Ning J, Sohani AR, Ferry JA, Mehta-Shah N, Dogan A, Liu H, Thormann N, Di Napoli A, Lade S, Piccolini J, Reyes R, Williams T, McCarthy CM, Hanson SE, Nastoupil L, Gaur R, Oki Y, Young KH, Miranda RN. Complete surgical excision is essential for the management of patients with breast implantassociated anaplastic large-cell lymphoma. J Clin Oncol 2016;34:160-168.

7. Mehta-Shah N, Clemens MW, Horwitz SM. How I treat breast implantassociated anaplastic large cell lymphoma. Blood 2018;132:1889-1898.

8. Bautista-Quach MA, Nademanee A, Weisenburger DD, Chen W, Kim YS. Implant-associated primary anaplastic large-cell lymphoma with simultaneous involvement of bilateral breast capsules. Clin Breast Cancer 2013;13:492-495.

9. Doren EL, Miranda RN, Selber JC, Garvey PB, Liu J, Medeiros L, Butler CE, Clemens MW. U.S. epidemiology of breast implant-associated anaplastic large cell lymphoma. Plast Reconstr Surg 2017;139:1042-1050.

10. Loch-Wilkinson A, Beath KJ, Knight RJW, Wessels WLF, Magnusson M, Papadopoulos T, Connell T, Lofts J, Locke M, Hopper I, Cooter R, Vickery K, Joshi PA, Prince HM, Deva AK. Breast implant-associated anaplastic large cell lymphoma in Australia and New Zealand: high-surface-area textured implants are associated with increased risk. Plast Reconstr Surg 2017;140:645-654.

11. de Boer $M$, van Leeuwen FE, Hauptmann $M$, Overbeek LIH, de Boer JP, Hijmering NJ, Sernee A, Klazen CAH, Lobbes MBI, van der Hulst R, Rakhorst $H A$, de Jong D. Breast implants and the risk of anaplastic large-cell lymphoma in the breast. JAMA Oncol 2018;4:335-341.

12. Campanale A, Boldrini R, Marletta M. 22 cases of breast implant-associated ALCL: awareness and outcome tracking from the Italian Ministry of Health. Plast Reconstr Surg 2018;141:11-19.

\title{
A Rare Cause of Cyanosis Since Birth: Hb M-Iwate
}

\section{Doğumdan Itibaren Mevcut Olan Siyanozun Nadir Bir Nedeni: Hb M-Iwate}

\author{
(D) Birgül Mutlu1, (1) Ebru Yılmaz Keskin2, (1) Ana Catarina Oliveira3, (1) Luis Relvas33, (1) Celeste Bento3 \\ ${ }_{1}^{1}$ Doruk Yıldırım Hospital, Clinic of Neonatal Intensive Care, Bursa, Turkey \\ 2Süleyman Demirel University Faculty of Medicine, Department of Pediatric Hematology and Oncology, Isparta, Turkey \\ ${ }^{3}$ Centro Hospitalar e Universitário de Coimbra, Clinic of Hematology, Coimbra, Portugal
}

\section{To the Editor,}

Cyanosis in an apparently healthy newborn baby may be caused by hemoglobin $(\mathrm{Hb})$ variants associated with the formation of methemoglobin. Such $\mathrm{Hb}$ variants are collectively known as $\mathrm{M}$ Hbs [1]. Hb M-Iwate [alpha2 87(F8) His>Tyr, HBA2:c.262C>T] is one of the $\mathrm{Hb}$ variants associated with methemoglobinemia [2].

Many $\mathrm{Hb}$ variants have been reported so far from Turkey $[3,4,5]$. We report herein a newborn baby from Bursa, Turkey, with methemoglobinemia and (pseudo) cyanosis having $\mathrm{Hb} \mathrm{M}$-Iwate as the underlying cause. To our knowledge, this is only the second report of $\mathrm{Hb} \mathrm{M}$-Iwate from Turkey, and more than four decades have passed since its first observation in Turkey in a 21-year-old male by Ozsoylu [6]. In addition, our case represents the first case of $\mathrm{Hb} \mathrm{M}$-Iwate from Turkey identified through genetic analysis of the $\alpha$-globin chain gene (HBA).
The boy, born at term to a 32-year-old mother, was noted to be cyanotic immediately after birth. He had findings of dyspnea and he received oxygen by hood.

In the family history, the mother had history of cyanosis, particularly in the peroral area, and was otherwise healthy. In addition, the maternal grandfather and his mother, who had migrated from Thessaloniki (Greece), also had a history of cyanosis.

The oxygen saturation $\left(\mathrm{SpO}_{2}\right)$ of the baby, measured by pulse oximeter, was between $50 \%$ and $60 \%$. Administration of oxygen did not result in an increase of the measured $\mathrm{SpO}_{2}$. In venous blood gas analysis, $\mathrm{pH}$ was $7.43, \mathrm{pCO}_{2}$ was 34.6 $\mathrm{mmHg}_{1} \mathrm{pO}_{2}$ was $45.3 \mathrm{mmHg}$, and the $\mathrm{p}_{50}$ value was $39.2 \mathrm{mmHg}$ (normal range: $22.6-29.4 \mathrm{mmHg}$ ). Methemoglobin relative concentration was 13.5\% (normal: <1.5\%). Complete blood 
count testing (Table 1) and echocardiographic examination were both normal.

In the follow-up of the case, findings of dyspnea resolved by the $3^{\text {rd }}$ postnatal day, although cyanosis persisted. The baby was discharged on the $4^{\text {th }}$ day in good condition.

Genetic analysis by Sanger sequencing of the $H B A$ genes identified a pathogenic variant, HBA2:c.262C $>T$, corresponding

\begin{tabular}{|c|c|c|}
\hline & Proband & Mother \\
\hline $\mathrm{Hb}(\mathrm{g} / \mathrm{dL})$ & 19.1 & 11.2 \\
\hline Hct $(\%)$ & 50.2 & 32.3 \\
\hline $\mathrm{RBC}\left(10^{6} / \mu \mathrm{L}\right)$ & 5.06 & 3.74 \\
\hline MCV (fL) & 99 & 87 \\
\hline MCH (pg) & 37.7 & 29.9 \\
\hline $\mathrm{MCHC}(\mathrm{g} / \mathrm{dL})$ & 38.0 & 34.2 \\
\hline RDW (\%) & 13.8 & 10.6 \\
\hline WBC $\left(10^{3} / \mu \mathrm{L}\right)$ & 23.2 & 9.0 \\
\hline Plt $\left(10^{3} / \mu \mathrm{L}\right)$ & 246 & 258 \\
\hline
\end{tabular}

to the already described $\mathrm{Hb} \mathrm{M}$-Iwate [alpha2 87(F8) His>Tyr] in the propositus and in his similarly affected mother (Figure $1 \mathrm{~A}$ ). This $\mathrm{Hb}$ variant could be detected by high-performance liquid chromatography (HPLC) (Beta-Thalassemia Program, Bio-Rad) (Figures 1B and 1C).

The M Hbs are transmitted in an autosomal dominant fashion and the existence of familial cyanosis with this pattern of inheritance was first recognized in Japan more than 200 years ago. In the 1950s, Shibata et al. [7] discovered the cyanosis to be due to an abnormal $\mathrm{Hb}$ in a large family with about 70 affected individuals. This abnormal $\mathrm{Hb}$ was later given the name $\mathrm{Hb} \mathrm{M}$-Iwate. In the vivid description of the clinical picture by Shibata et al. [8], "The patients with this disease are cyanotic from childhood, looking like a man who has been swimming in a cold water pool for a long time".

In conclusion, M Hbs should be considered in the differential diagnosis of cyanosis in the newborn period. HPLC can identify the presence of an $\mathrm{Hb}$ variant but gene sequencing is necessary for the identification of abnormal variants. Except for cosmetic consequences, the clinical course of patients with $\mathrm{Hb} \mathrm{M}$-Iwate is unremarkable.

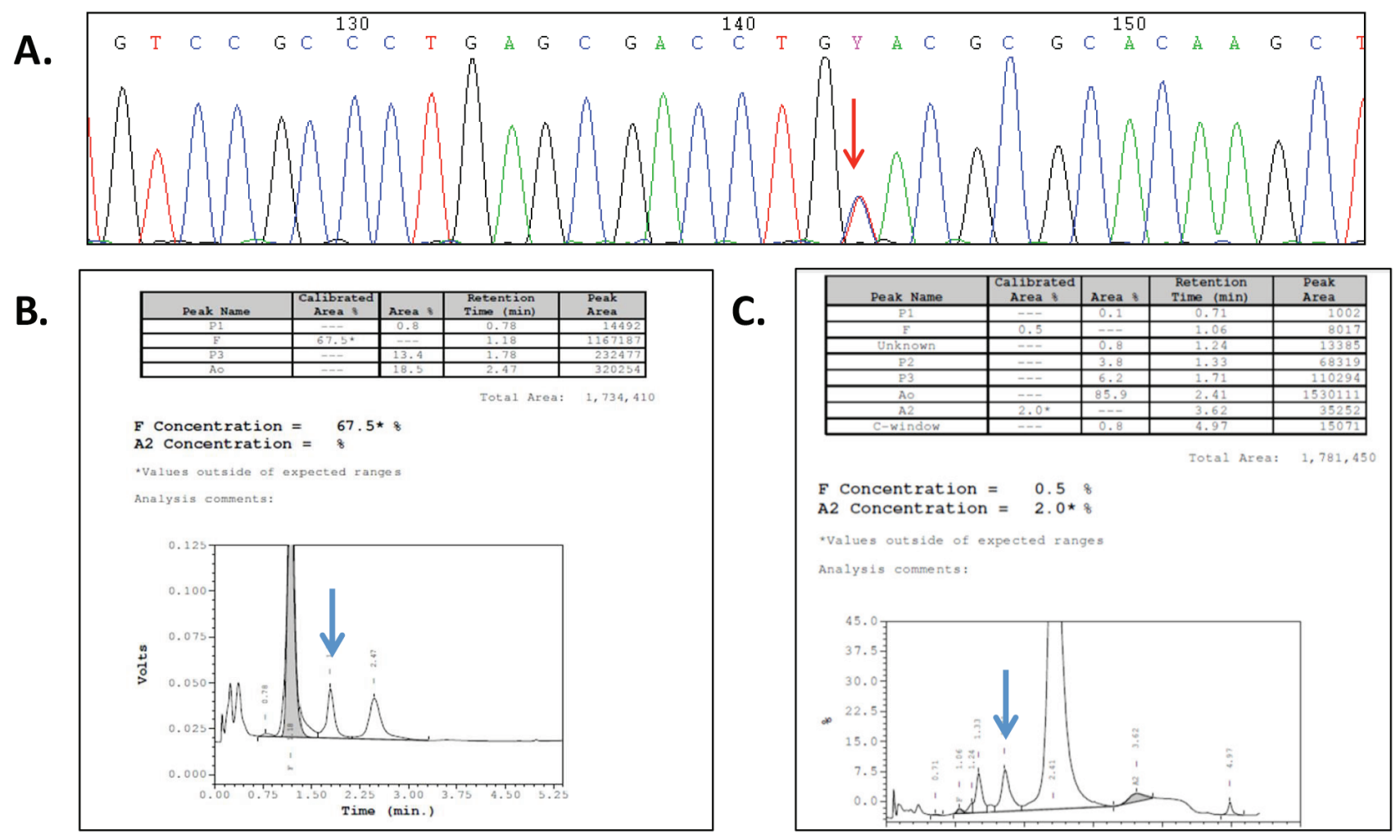

Figure 1. A) DNA sequence of a segment of exon 2 of the HBA2 gene showing the c.262C>T mutation. B) HPLC of the propositus (newborn). Peaks corresponding to Hb F (67.5\%), Hb M-Iwate (identifield as P3) (13.4\%; arrow), and Hb A (18.5\%) are observed. C) HPCL of the mother. Peaks corresponding to $\mathrm{Hb} F(2.5 \%), \mathrm{Hb}$ M-Iwate (identified as P3) (6.2\%; arrow), Hb A2 (2.0\%), and a small fraction (C-window), corresponding to $\mathrm{HbA} 2$ var $\left(\mathrm{alwate}_{2} \mathrm{\delta}_{2}\right)$, are observed. 
Keywords: Hb M-Iwate, Cyanosis, Methemoglobinemia

Anahtar Sözcükler: Hb M-Iwate, Siyanoz, Methemoglobinemi

Conflict of Interest: The authors of this paper have no conflicts of interest, including specific financial interests, relationships, and/or affiliations relevant to the subject matter or materials included.

\section{References}

1. Ashurst J, Wasson M. Methemoglobinemia: a systematic review of the pathophysiology, detection, and treatment. Del Med J 2011;83:203-208.

2. Thom CS, Dickson CF, Gell DA, Weiss MJ. Hemoglobin variants: biochemical properties and clinical correlates. Cold Spring Harb Perspect Med 2013;3:a011858.
3. Altay Ç. Abnormal hemoglobins in Turkey. Turk J Hematol 2002;19:63-74.

4. Akar $E_{1}$ Akar N. A review of abnormal hemoglobins in Turkey. Turk J Hematol 2007;24:143-145.

5. Akar N. An updated review of abnormal hemoglobins in the Turkish population. Turk J Hematol 2014;31:97-98.

6. Ozsoylu S. Congenital methemeoglobinemia due to hemoglobin M. Acta Haematol 1972;47:225-232.

7. Shibata S, Tamura A, luchi I, Takahashi H. Hemoglobin MI: demonstration of a new abnormal hemoglobin and hereditary nigremia. Acta Haematol Jap 1960;23:96-105.

8. Shibata S, Miyaji T, Ohba Y. Abnormal hemoglobins in Japan. Hemoglobin 1980;4:395-408.

\title{
Hodgkin Lymphoma, Tuberculosis, and Atypical Radiologic Image
} Hodgkin Lenfoma, Tüberküloz ve Atipik Radyolojik Görüntü

\author{
(1) Sora Yasri1 ${ }^{1}$ (1) Viroj Wiwanitkit² \\ ${ }^{1}$ KMT Primary Care Center, Bangkok, Thailand \\ 2Joseph Ayobabalola University, Ikeji-Arakeji, Nigeria
}

To the Editor,

We read the report by Büyükşimşek et al., [1] "Atypical Radiologic Image Characterized by Cavitary Lung Lesions in a Case of Hodgkin Lymphoma" (HL), with great interest. Büyükşimşek et al. [1] reported on a case of HL presenting with abnormal lung radiologic imaging and mentioned that "Disseminated cavitary lesions mimicking tuberculosis or other opportunistic infections in a case of $\mathrm{HL}$ is interesting and differential diagnosis is very important". We would like to share our ideas regarding this observation. Indeed, lung involvement due to lymphoma is possible. Nevertheless, the concurrence between $\mathrm{HL}$ and tuberculosis is detectable. In endemic areas of tuberculosis, such as Southeast Asia, tuberculosis screening is routinely done for any cancerous patients, including those with HL. Pathophysiologically, a common pathway that can result in increased risk for tuberculosis among patients with $\mathrm{HL}$ is the alteration of the antioxidative system. The depletion of glutathione (GSH) due to $\mathrm{HL}$ [2] can increase the risk for tuberculosis since GSH plays an important role in defending against mycobacterial pathogens [3]. Considering the present report by Büyükşimşek et al., [1] there is an interesting question of whether the present case of HL had a concurrent tuberculosis infection or not. Büyükşimşek et al. [1] used the QuantiFERON test for exclusion of tuberculosis. In a recent report, the sensitivity and specificity of the QuantiFERON test were found to be poor [4]. In cases with underlying vitamin B12 deficiency, false negative results by QuantiFERON are possible [5]. In a recent report, vitamin B12 deficiency was observable in 0.54\% of patients with $\mathrm{HL}$ and anemia [6].

Keywords: Hodgkin Lymphoma, Tuberculosis, Radiology

Anahtar Sözcükler: Hodgkin Lenfoma, Tüberküloz, Radyoloji

Conflict of Interest: The authors of this paper have no conflicts of interest including specific financial interests, relationships, and/or affiliations relevant to the subject matter or materials included.

\section{References}

1. Büyükşimşek $M$, Paydaş $S$, Gumurdulu $D$, Mirili $C$, Oğul $A$, Yetişir $A E$, Tohumcuoğlu M. Atypical radiologic image characterized by cavitary lung lesions in a case of Hodgkin lymphoma. Turk J Hematol 2019;36:6061. 